\title{
Intracranial Multiple Berry Aneurysms associated with Fibromuscular Dysplasia and Mixed Connective Tissue Disease
}

- Case Report-

\author{
Toshio Masuzawa, Noboru NaKaHaRa and Seiichi KobaYASHI*
}

Departments of Surgical Neurology and *Pathology, Jichi Medical School, Tochigi

\begin{abstract}
A rare case of multiple intracranial berry aneurysms associated with fibromuscular dysplasia (FMD) and mixed connective tissue disease (MCTD) is reported together with a review of the literature, particularly that of Japan.

The patient was a 59-year-old woman who had a subarachnoid hemorrhage during the course of MCTD. Angiographically, multiple intracranial aneurysms and "string of beads" were demonstrated in both cervical internal carotid arteries. The three aneurysms of the left internal carotid and middle cerebral arteries were treated surgically, and the remaining aneurysms in the right middle cerebral artery and at the top of the basilar artery were to be treated at a later date. Although the immediate postoperative course was uneventful, 1 month after surgery the patient died suddenly of sepsis with disseminated intravascular coagulation. At autopsy, FMD involving medial fibroplasia with aneurysms was found in the internal carotid and renal arteries. The intracranial aneurysms showed features typical of saccular aneurysms related to the arterial fork. Other than the aneurysms, no changes due to FMD were noted in the cerebral arteries. Although characteristic MCTD lesions were present in the visceral organs, no specific changes due to MCTD were seen in the brain.

Among the 29 patients with cervico-cephalic FMD reported in Japan, 15 had intracranial aneurysms. These included four cases of multiple aneurysms and 11 cases of rupture. No association between FMD and MCTD has been reported in the world literature.
\end{abstract}

Key words: mixed connective tissue disease, fibromuscular dysplasia, intracranial multiple aneurysms, subarachnoid hemorrhage, cerebral angiography

\section{Introduction}

Since the first description of renoarterial fibromuscular dysplasia (FMD) by Leadbetter and Burkland in $1938,{ }^{26)}$ its clinical importance in renovascular hypertension has been emphasized. Evidence of extrarenal FMD, including that of the cervical internal carotid artery, was reported by Palubinskas and Ripley in $1964 .^{39}$ ) A close correlation between cervico-cephalic FMD and intracranial aneurysms has been well established by a large number of studies. ${ }^{6,18,30-32,38,46,47)}$ However, only 28 cases of cervico-cephalic FMD have been recorded in the Japanese literature, including 14 cases associated

Received November 7, 1985; Accepted May 16, 1986 with cerebral aneurysms. ${ }^{1,13,16,20,23,33-36,50 \text { ) }}$

Mixed connective tissue disease (MCTD) is a recently described syndrome that shares various features of systemic lupus erythematosus, polymyositis, and progressive systemic sclerosis. ${ }^{41)}$ The disease is characterized by a high titer of antibody specific for the ribonuclear protein (RNP) component of extractable nuclear antigen (ENA). ${ }^{42)}$ Although several associated central nervous system disorders have been found, to our knowledge there have been no reports of intracranial aneurysm or subarachnoid hemorrhage in patients having both MCTD and FMD or MCTD alone. In this paper we describe the clinical course and autopsy findings in a 59-year-old woman with bilateral cervical FMD who had a subarachnoid hemorrhage during the course of MCTD. 


\section{Case Report}

A 59-year-old woman who had been diagnosed as having MCTD at the age of 47 was referred to our department with a diagnosis of subarachnoid hemorrhage based on lumbar puncture and computed tomography (CT) scan (Fig. 1). Her hypertension had been controlled with an antihypertensive drug.

Raynaud's phenomenon with sclerodactyly, puffiness of the hands and fingers, polyarthralgia, and sicca syndrome was verified. Laboratory studies yielded the following values: ESR, $115 \mathrm{~mm} / \mathrm{hr}$; RA test, positive; CRP, 5+; LE test, negative; antinuclear factor, positive; anti-DNA test (RIA), 75.5 units/ml; ENA antibody titer, 1:81,920 (RNP +); and test for antibody to the ribonuclease-resistant component of ENA, negative.

On admission to our department on December 10, 1984, the patient exhibited interstitial pneumonitis, pulmonary edema, cardiomegaly, congestive heart failure, mild disturbance of consciousness, and nuchal rigidity. Her four-vessel cerebral angiograms demonstrated multiple intracranial aneurysms and "string of beads" within the bilateral cervical internal carotid arteries (Fig. 2A). The aneurysms were located at the junction of the left internal carotid and posterior communicating arteries, at the bifurcation

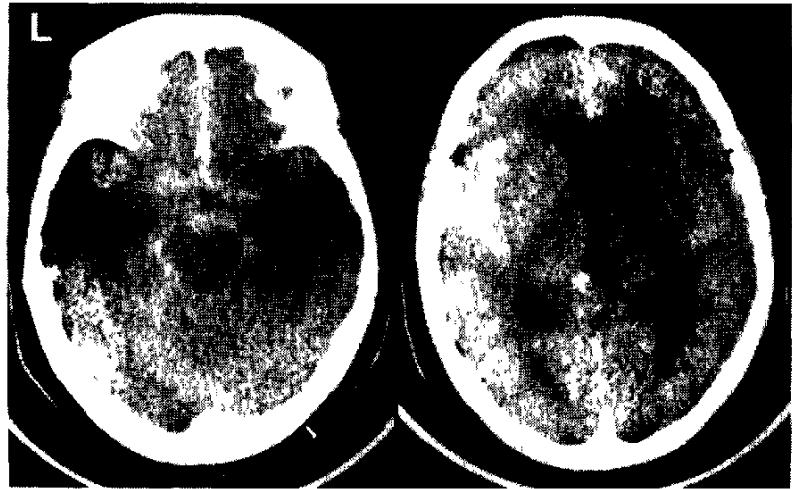

Fig. 1 Precontrast CT scan shows high-density areas of subarachnoid hemorrhage in the subarachnoid space and basal cisterns. No ventricular shift and dilatation are noted.

of the left internal carotid artery, at the trifurcations of both middle cerebral arteries $\left(M_{1}\right.$ and $M_{2}$ portion) (Figs. 2B and 3), and at the top of the basilar artery (Fig. 4). There was no evidence of hydrocephalus or infarction on the $\mathrm{CT}$ scan. After waiting for nearly 1 month for her condition to improve, on February 7, 1985, through a left osteoplastic craniotomy, we clipped the left internal carotid bifur-
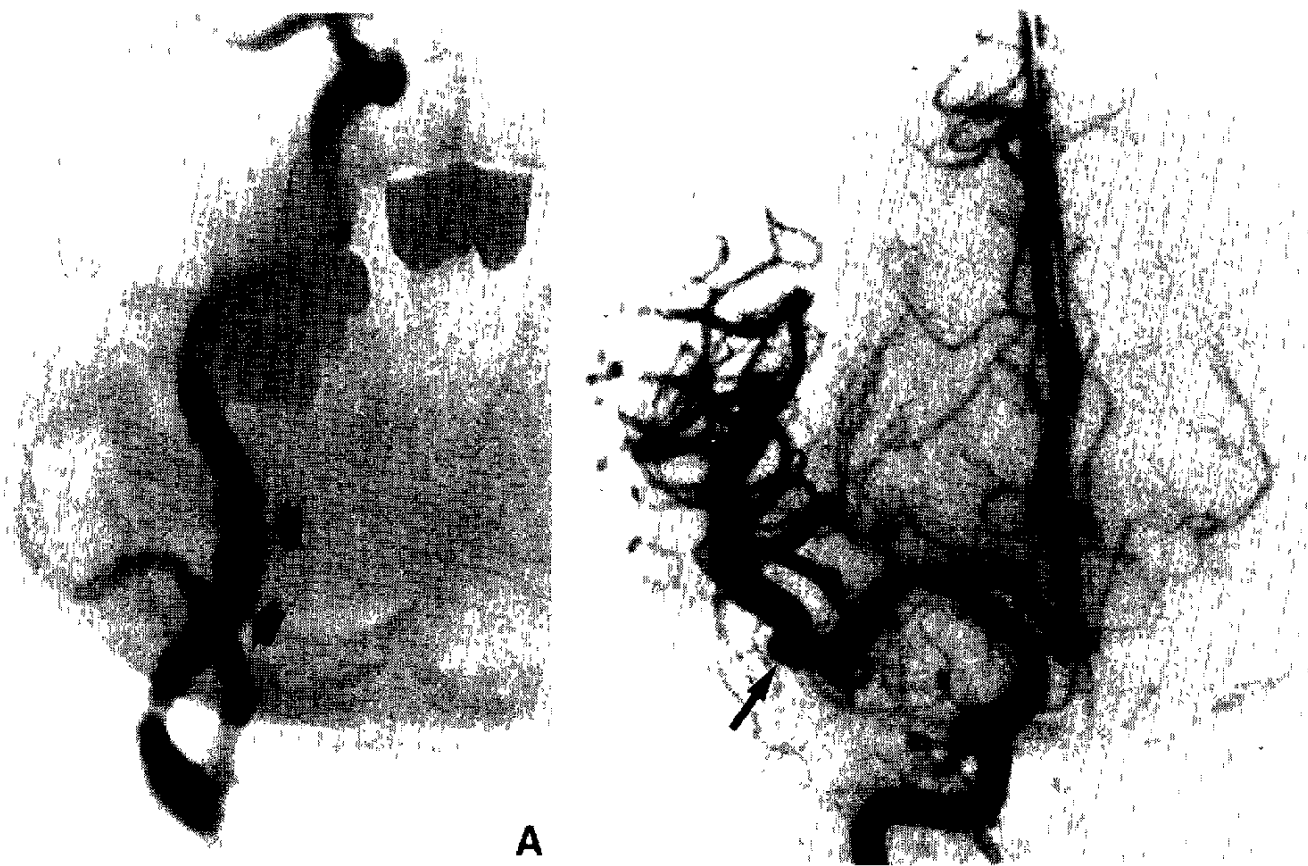

B

Fig. 2 Anteroposterior views of right internal carotid angiograms. A: A "string of beads" appearance is evident at the right cervical internal carotid artery (arrows). B: A berry aneurysm is visible at the trifurcation of the right middle cerebral artery (arrow). 


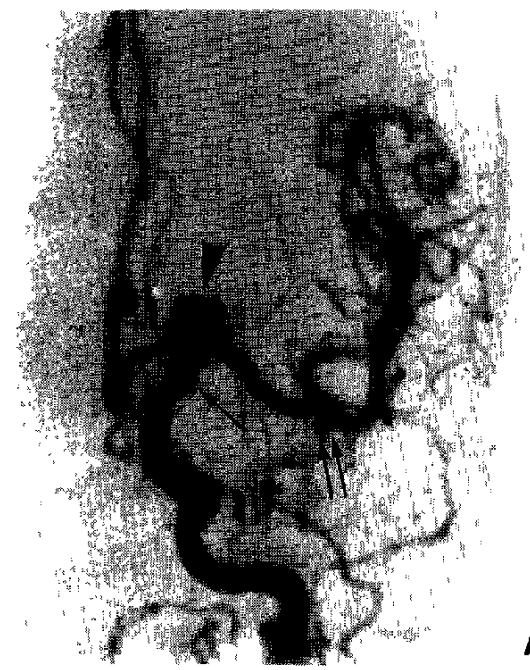

A

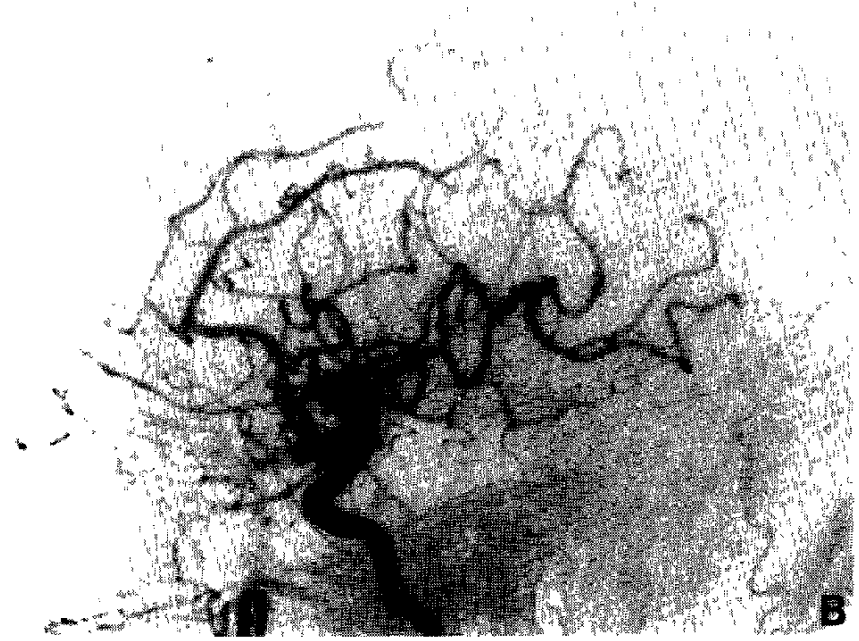

Fig. 3 Anteroposterior (A) and lateral (B) views of left internal carotid angiograms show a large berry aneurysm at the bifurcation of the left internal carotid artery (arrowhead), a medium-sized berry aneurysm at the trifurcation of the left middle cerebral artery (double arrow), and a small aneurysm at the junction of the left internal carotid and the posterior communicating arteries (arrow).

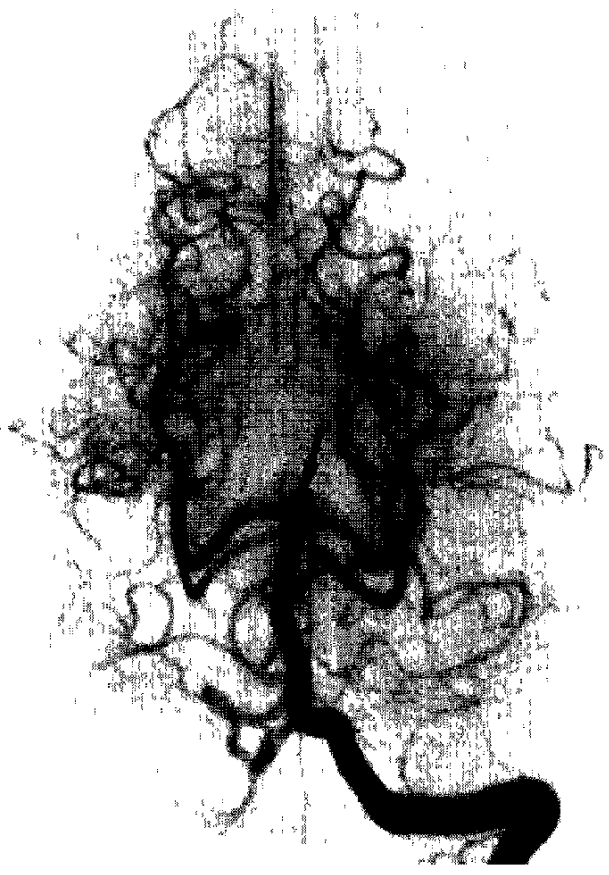

Fig. 4 Anteroposterior view of left vertebral angiogram. A berry aneurysm is seen at the top of the basilar artery (arrow).

cation and left middle cerebral aneurysms and wrapped the left internal carotid and posterior communicating aneurysm. The aneurysm of the left inter- nal carotid bifurcation was thought to have been responsible for the subarachnoid hemorrhage. Postoperatively, her course was uneventful and we hoped to eventually clip the untreated aneurysms. However, on February 24, 1985, 17 days after the initial operation, the patient died suddenly of sepsis with disseminated intravascular coagulation. An autopsy was performed.

Autopsy: The brain weighed $1,190 \mathrm{~g}$. There was mild hemosiderosis around the surgically treated aneurysms. In addition, there were untreated berry aneurysms, the largest of which was located at the bifurcation of the right middle cerebral artery $\left(\mathbf{M}_{1}-\right.$ $\mathrm{M}_{2}$ portion). It was dumbbell-shaped and was composed of nodules $8 \times 5 \times 4 \mathrm{~mm}$ and $4 \times 4 \times 4 \mathrm{~mm}$ in size. The aneurysm at the top of the basilar artery was $2 \times 2 \times 4 \mathrm{~mm}$ in size. Another aneurysm, $2 \mathrm{~mm}$ in diameter, was noted at the right $\mathrm{M}_{2}-\mathrm{M}_{3}$ portion; this aneurysm had not been detected by angiography. Histologically, all aneurysms showed features typical of saccular aneurysms related to the arterial fork. The tunica media was attenuated and merged with the fibromuscular tissue of the aneurysmal wall. The internal elastic lamina was lost at the neck of the aneurysm (Fig. 5A). Focal mural necrosis with mild hemosiderosis was noted in the wall of the aneurysm at the top of the basilar artery. Extensive calcium deposition was observed in the vascular walls of the globus pallidus. Other intracranial arteries were normal except for mild atherosclerosis. 

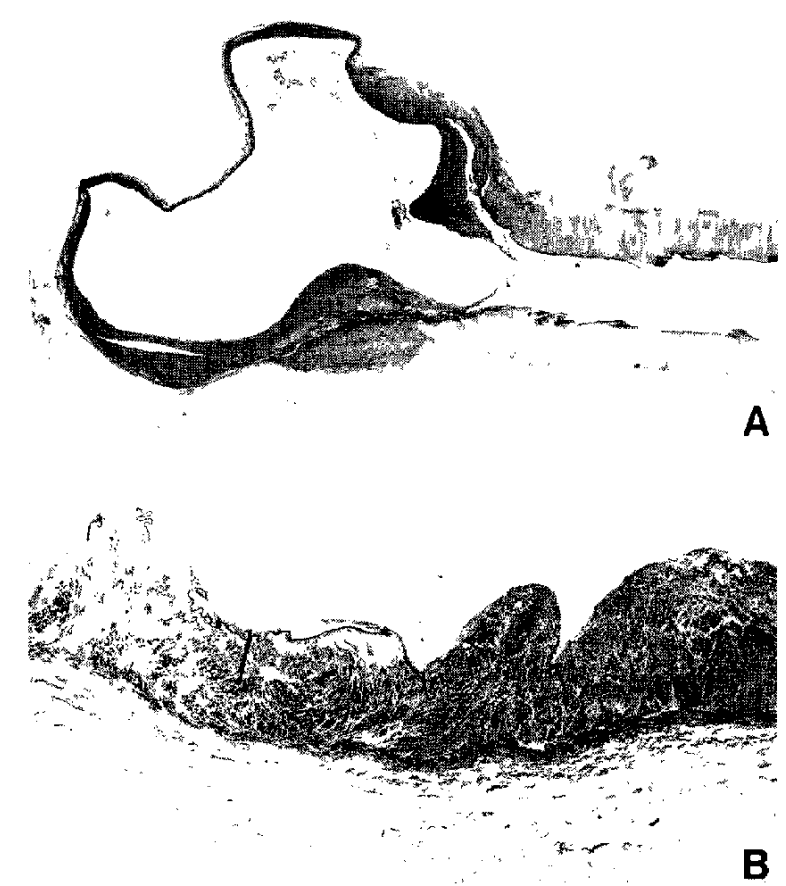

Fig. 5 A: A saccular aneurysm at the right $M_{2}-M_{3}$ portion. The internal elastic lamina is lost at its neck and no media is seen in most of the aneurysmal wall. Elastica van Gieson stain, $\times 25$. B: Longitudinal section of the left internal carotid artery showing typical features of FMD. Fibromuscular ridges alternating with areas of mural thinning are visible. The internal elastic lamina is interrupted and absent at the foci of mural thinning. Mallory's azan stain, $\times 40$.

In the bilateral cervical internal carotid arteries, fibromuscular ridges alternating with areas of mural thinning were evident in the longitudinal sections (Fig. 5B). The internal elastic lamina was discontinuous and disappeared in the areas of mural thinning. These histological findings are those of FMD of the type involving medial fibroplasia and aneurysm. The same histological features, although to a milder degree, were found in both renal arteries and in the external iliac and lienal arteries.

Pathological changes of MCTD were present in various organs. There were many central nuclei and irregularities of fiber size in the skeletal muscles. Marked round cell infiltration was noted in the salivary glands. Onion skin-like lesions were seen in the spleen. Diffuse mural fibrosis of the alimentary tract, especially of the lower esophagus, was identified. Subpleural fibrosis with honeycombing was revealed in the lungs and was associated with fibrous intimal lesions of the arteries; it was not observed outside the fibrotic lesions, in the kidneys, or in other organs.

\section{Discussion}

FMD is a segmental, non-atheromatous abnormality of intermediate-sized arteries. The etiology of FMD has been ascribed to microtrauma due to stretching of arteries, ${ }^{27)}$ mural ischemia caused by thrombotic or mechanical obliteration of the vaso vasorum, ${ }^{403}$ hormonal, metabolic, and immunologic factors, ${ }^{15,221}$ ergotamine medication, ${ }^{8}$ unknown connective tissue disorder, ${ }^{40)}$ and hereditary vascular disease. ${ }^{311}$

A histopathological classification of FMD was developed based on the renal arterial layer - intimal, medial, or adventitial - in which the lesions predominate. ${ }^{14)}$ The most frequently observed pattern is that of medial FMD. Medial lesions are classified into four subgroups according to the predominant histopathological features: (a) medial fibroplasia with mural aneurysm, showing multistenosis due to thickened fibromuscular ridges alternating with areas of marked mural thinning (aneurysm) and producing "string of beads" arteriograms; (b) medial hyperplasia; (c) perimedial fibroplasia; and (d) medial dissection. The lesions of the internal carotid artery in our patient corresponded to medial fibroplasia with aneurysm.

FMD of the internal carotid artery, angiographically characterized by "string of beads," was first described by Connett and Lansche, ${ }^{5)}$ and then by others. The angiographic incidence of cervicocephalic FMD was less than $1 \%$ in several series of cerebral angiograms: less than $0.32 \%$ in that of Houser and Baker, ${ }^{(8)} 0.6 \%$ in that of Corrin et al., ${ }^{6}$ ) $0.53 \%$ in that of So et al. ${ }^{46)}$ and $0.9 \%$ in that of Mettinger and Ericson. ${ }^{31)}$

Of clinical importance is the association between intracranial berry aneurysms and FMD. Aneurysms were found in 19 of 37 patients $(51 \%)$ in Mettinger and Ericson's series ${ }^{31)}$ and in 27 of 70 patients (39\%) in that of Manelfe et al. ${ }^{27)}$ Frens et al ${ }^{99}$ reported 23 intracranial aneurysms diagnosed angiographically in 109 reported cases of FMD of the cervical arteries.

In the literature limited to Japanese patients, only 29 patients with cervico-cephalic FMD have been reported ${ }^{1,12,13,16,19-21,23,33-36,43,44,49,50,52)}$ (including our patient) (Table 1), of whom 19 (66\%) were female. The female-to-male ratio is similar to that reported in the Western literature. ${ }^{301}$ The females' ages ranged from 20 to 67 years (average, 49.3 years) and the males' ages from 20 to 72 years (average, 45.3 years). Of 24 patients with the description of blood pressure, six 
(25\%) had arterial hypertension, three of whom with pathological changes (dilatation, "string of beads," stenosis) on renal angiograms. Eighteen (75\%) were normotensive, four of whom with pathological changes ("string of beads," stenosis) on renal angiograms. Five of the 29 patients had transient ischemic attack and five had cerebral infarction. Ten of 15 patients $(67 \%)$ with bilateral cervical or vertebral FMD had a marked tendency to develop intracranial aneurysms. Of the nine patients having bilateral cervical FMD with intracranial aneurysms, three had multiple aneurysms. FMD of the internal carotid artery was accompanied by aneurysms in the anterior half of Willis's ring, whereas FMD of the vertebral artery was associated with aneurysms in the posterior half of the ring. ${ }^{16)}$ Fifteen $(52 \%)$ had intracranial cerebral aneurysms; these ruptured in 11 patients and included multiple aneurysms in four. In three cases these aneurysms were located on the anterior communicating artery ${ }^{33-35)}$ and, in one case each, on the internal carotid artery, ${ }^{23)}$ on the middle cerebral artery, ${ }^{201}$ the anterior cerebral artery, ${ }^{13)}$ the junction of the internal carotid and posterior communicating arteries, ${ }^{50)}$ the true posterior communicating artery ${ }^{16)}$ the junction of the vertebroposterior inferior cerebellar artery, ${ }^{17}$ the posterior cerebral artery, ${ }^{34)}$ and the basilar artery ${ }^{361}$ (Table 1). In three of four cases of multiple intracranial aneurysms, angiograms demonstrated the characteristic "string of beads" appearance in the bilateral cervical internal carotid artery. The multiple aneurysms were distributed on the anterior cerebral artery in the first case, ${ }^{33}$ on the right ophthalmic artery and junction of the internal carotid and posterior communicating arteries in the second, ${ }^{33)}$ on the left anterior cerebral, middle cerebral, and basilar arteries in the third, ${ }^{36)}$ and on the left internal carotid bifurcation, the junction of the left internal carotid and

Table 1 Summary of 29 cases of cervico-cephalic FMD in Japanese patients

\begin{tabular}{|c|c|c|c|c|c|c|c|}
\hline Author (Year) & $\begin{array}{l}\text { Age } \\
\& \text { sex }\end{array}$ & $\begin{array}{l}\text { Location } \\
\text { of FMD }\end{array}$ & $\begin{array}{l}\text { Angiographic } \\
\text { "string of } \\
\text { beads" } \\
\text { appearance }\end{array}$ & $\begin{array}{l}\text { Intracranial } \\
\text { aneurysm } \\
\text { (*ruptured) }\end{array}$ & $\begin{array}{c}\text { Renal } \\
\text { angiography }\end{array}$ & $\begin{array}{l}\text { Hyper- } \\
\text { tension }\end{array}$ & $\begin{array}{l}\text { Autopsy } \\
\text { or FMD } \\
\text { histology }\end{array}$ \\
\hline $\begin{array}{l}\text { Handa et al. } \\
(1970)^{13}\end{array}$ & $50 \mathrm{M}$ & bil. ICA & + & ${ }^{*}$ rt. ACA & dilatation & + & \\
\hline $\begin{array}{l}\text { Hamaguchi et al. } \\
(1976)^{12)}\end{array}$ & $43 \mathrm{~F}$ & lt. ICA & $\begin{array}{l}\text { irregular } \\
\text { stenosis }\end{array}$ & TIA & "string of beads", & & histology \\
\hline$\underset{(1978)^{50)}}{\text { Tsumuraya et al. }}$ & $54 \mathrm{M}$ & lt. ICA & + & ${ }^{*}$ rt. IC-PcomA & & - & \\
\hline $\begin{array}{l}\text { Shindo et al. } \\
\qquad(1978)^{44)}\end{array}$ & $52 \mathrm{~F}$ & bil. ICA & + & acoustic neurinoma & & & \\
\hline $\begin{array}{l}\text { Abdul-Rahman } \\
\text { et al. }(1978)^{1)}\end{array}$ & $72 \mathrm{M}$ & rt. ICA & irregularity & ${ }^{*}$ lt. VA-PICA & & - & $\begin{array}{l}\text { autopsy, } \\
\text { histology }\end{array}$ \\
\hline $\begin{array}{l}\text { Ishii et al. } \\
\qquad(1979)^{21)}\end{array}$ & $47 \mathrm{~F}$ & rt. CCA & + & infarction & & & \\
\hline $\begin{array}{l}\text { Shimojo et al. } \\
(1979)^{43)}\end{array}$ & $68 \mathrm{M}$ & rt. ICA & + & TIA & & & histology \\
\hline $\begin{array}{l}\text { Nishimoto } \\
\text { and Onbe } \\
(1979)^{33)}\end{array}$ & $43 \mathrm{~F}$ & bil. ICA & + & multiple: ACA & "string of beads" & - & \\
\hline "I & $57 \mathrm{~F}$ & bil. ICA & + & TIA & & - & \\
\hline $1 "$ & $66 \mathrm{~F}$ & lt. ICA & + & ${ }^{*} \mathrm{~A} \operatorname{com} \mathrm{A}$ & normal & - & \\
\hline 11 & $45 \mathrm{~F}$ & bil. ICA & + & $\begin{array}{c}\text { multiple: rt. OphA, } \\
\text { rt. IC-PcomA }\end{array}$ & single stenosis & - & \\
\hline " & $43 F$ & rt. ICA & + & seizure & "string of beads" & - & \\
\hline $\begin{array}{l}\text { Yamamoto et al. } \\
(1979)^{52)}\end{array}$ & $33 \mathrm{M}$ & It. ICA & + & infarction & & - & \\
\hline $\begin{array}{l}\text { Teraura et al. } \\
(1979)^{49)}\end{array}$ & $20 \mathrm{~F}$ & \multicolumn{2}{|c|}{$\begin{array}{l}\text { multiple constrictions } \\
\text { and dilatations in } \\
\text { intracranial arteries }\end{array}$} & $\begin{array}{l}\text { seizure, } \\
\text { rubella infection }\end{array}$ & "string of beads" & - & $\begin{array}{l}\text { histology } \\
\text { (STA) }\end{array}$ \\
\hline$\underset{(1980)^{23)}}{\text { Kobayashi et } a l .}$ & $20 \mathrm{M}$ & $\begin{array}{l}\text { rt. ICA (in- } \\
\text { cluding } \\
\text { carotid } \\
\text { siphon) }\end{array}$ & + & ${ }^{*} \mathrm{rt}$. ICA (fusiform) & normal & - & \\
\hline
\end{tabular}


posterior communicating arteries, the bilateral middle cerebral arteries, and the basilar artery in the fourth (our patient).

In contrast to Mettinger and Ericson's report, ${ }^{31)}$ the intracranial aneurysms described in the Japanese literature were not most often found on the same side as the most affected extracranial carotid artery. Among Japanese FMD patients, only one-fourth had hypertension and no cerebral hemorrhage (apart from aneurysmal rupture) was reported. Further, only five of 15 patients with intracranial aneurysms had hypertension. Mettinger and Ericson ${ }^{31)}$ did not consider intracranial aneurysms to be a secondary effect of hypertension, as Stehbens ${ }^{48)}$ described, because only nine of their 19 patients with aneurysms were hypertensive.

Although central nervous system involvement is extremely rare in MCTD, some neurological abnormalities have been reported: psychosis, aseptic men- ingitis, convulsion, and cerebellar ataxia., ${ }^{2,3)}$ There have been no reports of MCTD associated with subarachnoid hemorrhage or intracranial aneurysms. Subarachnoid hemorrhage has occasionally been reported in patients with systemic lupus erythematosus, but it has not been determined whether the hemorrhage had been caused by ruptured aneurysms. ${ }^{4,11,29,37)}$ No reports are available concerning MCTD associated with FMD or vice versa.

Histologically, the blood vessel walls in MCTD demonstrate various changes. In the branches of the pulmonary arteries ${ }^{7,28)}$ and in the renal interlobular arteries, ${ }^{25)}$ the walls are markedly narrowed by intimal proliferation. Proliferative intimal lesions in medium- to large-sized arteries have also been reported. ${ }^{45)}$ Postmortem histological examinations of MCTD patients have uncovered no remarkable changes in the brain or its vessels. ${ }^{24,28)}$ This was also true in our case.

Table 1, page 2

\begin{tabular}{|c|c|c|c|c|c|c|c|}
\hline Author (Year) & $\begin{array}{l}\text { Age } \\
\& \text { sex }\end{array}$ & $\begin{array}{l}\text { Location } \\
\text { of FMD }\end{array}$ & $\begin{array}{l}\text { Angiographic } \\
\text { "string of } \\
\text { beads" } \\
\text { appearance }\end{array}$ & $\begin{array}{l}\text { Intracranial } \\
\text { aneurysm } \\
\text { (*ruptured) }\end{array}$ & $\begin{array}{c}\text { Renal } \\
\text { angiography }\end{array}$ & $\begin{array}{l}\text { Hyper- } \\
\text { tension }\end{array}$ & $\begin{array}{l}\text { Autopsy } \\
\text { or FMD } \\
\text { histology }\end{array}$ \\
\hline$\underset{(1981)^{34)}}{\text { Nishimoto }}$ & $37 \mathrm{~F}$ & bil. ICA & + & TIA & normal & + & \\
\hline 11 & $41 F$ & rt. ICA & + & infarction & & - & \\
\hline$"$ & $49 \mathrm{~F}$ & bil. ICA & + & ${ }^{*} \mathrm{Acom} A$ & & - & \\
\hline " & $50 \mathrm{~F}$ & $\begin{array}{l}\text { bil. ICA, } \\
\text { lt. VA }\end{array}$ & + & *rt. PCA & not done & + & \\
\hline "1 & $64 \mathrm{~F}$ & rt. ICA & + & infarction & not done & - & \\
\hline $\begin{array}{l}\text { Ikari et al. } \\
\qquad(1981)^{19)}\end{array}$ & $20 \mathrm{M}$ & rt. ICA & + & infarction & & & \\
\hline$\underset{(1982)^{35)}}{\text { Nishimoto }}$ & $65 \mathrm{~F}$ & bil. VA & + & TIA & & - & \\
\hline$"$ & $67 \mathrm{~F}$ & bil. ICA & + & facial spasm & & - & \\
\hline 11 & $72 \mathrm{M}$ & bil. ICA & + & ${ }^{*} \mathrm{Acom} A$ & & - & \\
\hline $\begin{array}{l}\text { Ohuchi et al. } \\
\qquad(1984)^{36)}\end{array}$ & $34 \mathrm{~F}$ & rt. ICA & - & $\begin{array}{c}\text { multiple (SAH+): } \\
\text { lt. ACA (1), it. } \\
\text { MCA (2), BA (4) }\end{array}$ & "string of beads" & + & $\begin{array}{l}\text { autopsy, } \\
\text { histology }\end{array}$ \\
\hline " & $30 \mathrm{M}$ & bil. ICA & $\begin{array}{l}\text { complete } \\
\text { occlusion }\end{array}$ & $\mathrm{BA}$ & stenosis & + & \\
\hline $\begin{array}{l}\text { Hasue and Miwa } \\
(1985)^{16)}\end{array}$ & $34 \mathrm{M}$ & bil. VA & + & $*$ true $\mathbf{P} \operatorname{com} A$ & & - & $\begin{array}{l}\text { histology } \\
\text { (OA) }\end{array}$ \\
\hline $\begin{array}{l}\text { Imaya et al. } \\
(1985)^{20)}\end{array}$ & $54 \mathrm{~F}$ & $\begin{array}{l}\text { bil. ICA, } \\
\text { bil. VA }\end{array}$ & + & rt. MCA & normal & - & \\
\hline Present case & $59 \mathrm{~F}$ & bil. ICA & + & $\begin{array}{l}\text { multiple: }{ }^{*} \text { It. IC } \\
\text { bifurcation, } \\
\text { It. IC-PcomA, } \\
\text { bil. MCA, BA }\end{array}$ & not done & + & $\begin{array}{l}\text { autopsy, } \\
\text { histology }\end{array}$ \\
\hline
\end{tabular}

ICA: internal carotid artery, CCA: common carotid artery, VA: vertebral artery, ACA: anterior cerebral artery, PcomA: posterior communicating artery, PICA: posterior inferior cerebellar artery, AcomA: anterior communicating artery, OphA: ophthalmic artery, PCA: posterior cerebral artery, MCA: middle cerebral artery, BA: basilar artery, STA: superficial temporal artery, OA: occipital artery, TIA: transient ischemic attack, SAH: subarachnoid hemorrhage. The blank columns indicate that there was no mention of the matter in the published report. 
The location of aneurysms and absence of hypertension in many patients with FMD suggests that the aneurysms are manifestations of the morphological process of FMD itself rather than secondary effects of hypertension. ${ }^{30)}$ Some reported autopsy cases have provided evidence of histopathological changes of FMD in intracranial aneurysms and adjacent cerebral arteries. ${ }^{1,17,51)}$ The postmortem examination of our patient showed no pathological changes, including those of MCTD and/or FMD, in the cerebral arterial walls outside of the aneurysms.

Both intracranial aneurysms and FMD of the medial fibroplastic type are characterized by degeneration or focal absence of the tunica media and disruption and loss. of the internal elastic membrane. ${ }^{52)}$ The weak points in the walls of predisposed cerebral arteries are considered responsible for the development of intracranial aneurysms even in the absence of a diseased renal artery or hypertension. ${ }^{101}$ Abdul-Rahman et al. ${ }^{\text {") }}$ observed a 50-year-old woman in whom an intracranial aneurysm and cervical internal carotid FMD lesion developed that had not been revealed on the first angiogram 8 years previously. Cervical FMD is a dynamic and progressive disease in some cases. ${ }^{52)}$ Undetected connective tissue disorders are probably responsible for the development of arterial lesions in fibromuscular dysplasia. ${ }^{40)}$

The histological similarities between intracranial aneurysms and other types of aneurysms in patients with FMD, the frequency of intracranial aneurysms in patients with extracranial FMD, and the similar worldwide sex and age incidences suggest a common etiology. ${ }^{\text {s) }}$

\section{Acknowledgment}

We thank Miss Masako Sakamoto for her help in the preparation of the manuscript.

\section{References}

1) Abdul-Rahman AM, Abu-Salih, Brun A, Kin H, Ljunggren B, Misukami M, Moquist-Olsson I, Sahlin $\mathrm{Ch}$, Svendgaard NA, Thulin C-A: Fibromuscular dysplasia of the cervico-cephalic arteries. Surg Neurol 9: 217-222, 1978

2) Bennett RM, Bong DM, Spargo BH: Neuropsychiatric problems in mixed connective tissue disease. $A m J$ Med 65: 955-962, 1978

3) Bennett RM, O'Connell DJ: Mixed connective tissue disease: A clinicopathologic study of 20 cases. Semin Arthritis Rheum 10: 25-51, 1980

4) Clark EC, Bailey AA: Neurological and psychiatric signs associated with systemic lupus erythematosus. JAMA 160: 455-457, 1956

5) Connett MC, Lansche JM: Fibromuscular hyperplasia of the internal carotid artery: Report of a case. Ann Surg 162: 59-62, 1965

6) Corrin LS, Sandok BA, Houser OW: Cerebral ischemic events in patients with carotid artery fibromuscular dysplasia. Arch Neurol 38: 616-618, 1981

7) Eulderink F, Cats A: Fatal primary pulmonary hypertension in mixed connective tissue disease. $Z$ Rheumatol 40: 25-29, 1981

8) Fievez M: Relations ergotisme-hyperplasie fibromusculaire. Nouv Presse Med 23: 1735, 1975

9) Frens DB, Petajan JH, Anderson R, Deblanc HJ Jr: Fibromuscular dysplasia of the posterior cerebral artery: Report of a case and review of the literature. Stroke 5: 161-166, 1974

10) Galligioni F, Iraci G, Marin G: Fibromuscular hyperplasia of the extracranial internal carotid artery. J Neurosurg 34: 647-651, 1971

11) Gold AP, Yahr MD: Childhood lupus erythematosus: A clinical and pathological study of the neurological manifestations. Trans Amer Neurol Ass 85: 96-102, 1960

12) Hamaguchi $K$, Fukuuchi $Y$, Iwagaki $H$, Tanahashi $\mathrm{N}$, Hata J, Ishitobi $\mathrm{K}$ : A case of fibromuscular dysplasia of the internal carotid artery confirmed histologically in the resected specimen. Rinsho Shinkeigaku 16: 83-84, 1976 (in Japanese)

13) Handa J, Kamijo Y, Handa H: Fibromuscular hyperplasia: Report of a case of fibromuscular disease associated with intracranial aneurysm. No To Shinkei 22: 191-196, 1970 (in Japanese)

14) Harrison EG, McCormack LJ: Pathological classification of renal arterial disease in renovascular hypertension. Mayo Clin Proc 46: 161-167, 1971

15) Hartman JD, Young I, Bank AA, Rosenblatt SA: Fibromuscular hyperplasia of internal carotid arteries. Stroke in a young adult complicated by oral contraceptives. Arch Neurol 25: 295-301, 1971

16) Hasue $M$, Miwa $T$ : Cerebral ancurysm associated with fibromuscular dysplasia of the bilateral vertebral artery and occipital artery. Case report. Neurol Med Chir (Tokyo) 25: 381-386, 1985 (in Japanese)

17) Hill LD, Antonius JL: Arterial dysplasia. An important surgical lesion. Arch Surg (Chicago) 90: 585595,1965

18) Houser OW, Baker HL: Fibromuscular dysplasia and other uncommon diseases of the cervical carotid artery: Angiographic aspects. Amer $J$ Roentgen 104: 201-212, 1968

19) Ikari $\mathrm{H}$, Miyamoto $\mathrm{K}$, Yoshii $\mathrm{U}$, Hasegawa $\mathrm{O}$, Ono K, Hatori H, Sekine S, Inoue S, Kaneko Y: A case of juvenile cerebral infarction associated with fibromuscular dysplasia of the right internal carotid artery. Nippon Naika Gakkai Zasshi 70: 938, 1981 (in Japanese)

20) Imaya H, Kobayashi S, Okada T, Murayama K, 
Nakazawa S: A case of fibromuscular dysplasia with middle cerebral aneurysm. No Shinkei Geka 13: 653658,1985 (in Japanese)

21) Ishii $M$, Maeda $M$, Itoo $M$, Nakajima $K$, Sumie $H$ : Fibromuscular dysplasia associated with RIND. Rinsho Shinkeigaku 19: 249, 1979 (in Japanese)

22) Kaufman HH: Fibromuscular hyperplasia of the carotid artery. In a case associated with an arteriovenous malformation. Arch Neurol 22: 299-304, 1970

23) Kobayashi I, Enokida M, Nagura H: A case of intraand extracranial fibromuscular dysplasia. Shinkei Naika 13: 178-181, 1980 (in Japanese)

24) Kobayashi H, Sano T, Ii K, Hizawa K, Yamanoi A, Otsuka T: Mixed connective tissue disease with fatal pulmonary hypertension. Acta Pathol Jpn 32: 11211129,1982

25) Kumagai $Y$, Abe $C$, Hirano $T$, Fukuda $Y$, Shiokawa $Y$ : Mixed connective tissue disease after breast augmentation which terminated in scleroderm kidney. An autopsy case report of human adjuvant disease. Ryumachi 21: 171-176, 1981 (in Japanese)

26) Leadbetter WF, Burkland CE: Hypertension in unilateral renal disease. $J$ Urol 39: 611-625, 1938

27) Manelfe C, Clariesse J, Fredy D, André JM, Crouzet $\mathrm{G}$ : Fibromuscular dysplasia of the cervico-cephalic arteries. Report of 70 cases. I Neuroradiol 1: 149 231,1974

28) Manthrope $R$, Elling $H$, Van der Meulen JT, Sørensen SF: Two fatal cases of mixed connective tissue disease. Description of case histories terminating as progressive systemic sclerosis. Scand $J$ Rheumatol 9: 7-10, 1980

29) Matsumoto $Y$, Ishihara J, Ozika K, Yamagata K, Takikawa K: A case of systemic lupus erythematosus with subarachnoidal bleeding. Nippon Naika Gakkai Zasshi 65: 1045-1049, 1976 (in Japanese)

30) Mettinger KL: Fibromuscular dysplasia and the brain. II. Current concept of the disease. Stroke 13: $53-58,1982$

31) Mettinger KL, Ericson K: Fibromuscular dysplasia and the brain. Observations on angiographic, clinical and genetic characteristics. Stroke 13: 46-52, 1982

32) Morris GC, Lechter A, DeBakey ME: Surgical treatment of fibromuscular disease of the carotid arteries. Arch Surg (Chicago) 96: 636-643, 1968

33) Nishimoto A, Onbe H: Investigation of fibromuscular dysplasia. A report by the Research Committee on Spontaneous Occlusion of the Circle of Willis ("Moyamoya Disease") of the Ministry of Health and Welfare of Japan. 1979, pp 147-158

34) Nishimoto $A$, Ueda $K$, Honma $Y$ : Investigation of fibromuscular dysplasia of the cervicocephalic arterial system. A report by the Research Committee on Spontaneous Occlusion of the Circle of Willis ("Moyamoya Disease") of the Ministry of Health and Welfare of Japan. 1981, pp 28-38

35) Nishimoto A, Ueda K, Honma Y: Summary of cases of fibromuscular dysplasia of the cervicocephalic arterial system. A report by the Research Committee on Spontaneous Occlusion of the Circle of Willis ("Moyamoya Disease") of the Ministry of Health and Welfare of Japan. 1982, pp 28-39

36) Ohuchi Y, Tagawa H, Sakurai K, Yamakado K, Tanaka S: Renovascular hypertension due to fibromuscular dysplasia associated with cerebral aneurysm: Two cases occurred in sibling. Nippon Naika Gakkai Zasshi 73: 33-42, 1984 (in Japanese)

37) Osame M, Igata A: Neurologic disorders in SLE. A review in Japanese literatures. Rinsho To Kenkyu 49: 618-623, 1972 (in Japanese)

38) Osborn AG, Anderson RE: Angiographic spectrum of cervical and intracranial fibromuscular dysplasia. Stroke 8: 617-626, 1977

39) Palubinskas AJ, Ripley HR: Fibromuscular hyperplasia in extrarenal arteries. Radiology 82: 451-455, 1964

40) Rothfield NJH: Experimental fibromuscular arterial dysplasia. Radiology 93: 1291-1297, 1969

41) Sharp GC, Irvin S, Tan EM, Gould RG, Holman HR: Mixed connective tissue disease. An apparently distinct rheumatic disease syndrome associated with a specific antibody to an extractable nuclear antigen (ENA). Am J Med 52: 148-159, 1972

42) Sharp GC, Irvin WS, May CM, Holman HR, McDuffie FC, Hess EV, Schmid FR: Association of antibodies to ribonucleoprotein and Sm antigens with mixed connective tissue disease, systemic lupus erythematosus, and other rheumatic disease. $N$ Engl J Med 295: 1149-1154, 1976

43) Shimojo S, Utsunomiya Y, Toyohara K, Hirayama $\mathrm{T}$, Ichikawa K: Fibromuscular dysplasia of the internal carotid artery. Shinkei Naika 10: 498-501, 1979 (in Japanese)

44) Shindo M, Takahashi M, Tamagawa $Y$, Kotani R, Nakano Y, Arii H: A case of fibromuscular dysplasia in the internal carotid artery. Rinsho Hoshasen 23: 179-180, 1978 (in Japanese)

45) Singsen BH, Swanson VL, Heuser ET, Hanson V, Landing $\mathrm{BH}$ : A histologic evaluation of mixed connective tissue disease in childhood. Am J Med 68: $710-717,1980$

46) So EL, Toole JF, Dalal P, Moody DM: Cephalic fibromuscular dysplasia in 32 patients. Clinical findings and radiologic features. Arch Neurol 38: $619-622,1981$

47) Stanley JC, Gewertz BL, Bove EL, Sottiurai V, Fry WJ: Arterial fibrodysplasia: Histopathologic character and current etiologic concepts. Arch Surg 110: 561-566, 1975

48) Stehbens WE: Pathology of the Cerebrat Blood Vessel. St. Louis, CV Mosby, 1972, p 625

49) Teraura $T$, Terano M, Uchida $Y$, Otsuka S: A case of intracranial fibromuscular dysplasia associated with increased antibody for rubella. Nippon Geka Hokan 48: 393-399, 1979 (in Japanese)

50) Tsumuraya $K$, Ichikawa $N$, Ijima $K$, Itahara $K$ : Fibromuscular dysplasia of internal carotid artery as- 
sociated with intracranial saccular aneurysm. Shinkei Naika 9: 387-390, 1978 (in Japanese)

51) Wylie EJ, Binkley FM, Palubinskas AJ: Extrarenal fibromuscular hyperplasia. Amer J Surg 112: 149155,1966

52) Yamamoto I, Kageyama N, Usui K, Yoshida J: Fibromuscular dysplasia of the internal carotid artery. Unusual angiographic changes with progression of clinical symptoms. Acta Neurochir (Wien) 50 :
292-298, 1979

Address reprint requests to: T. Masuzawa, M.D., Department of Surgical Neurology, Jichi Medical School, 3,311-1 Yakushiji, Minamikawachi-machi, Kawachi-gun, Tochigi 329-04, Japan. 